\title{
Why the CHIPS Are Down: Stock Buybacks and Subsidies in the U.S. Semiconductor Industry
}

\author{
William Lazonick and Matt Hopkins*
}

Working Paper No. 165

\section{September $27^{\text {th }}, 2021$ (revised November $1^{\text {st }}, 2021$ )}

\begin{abstract}
The Semiconductor Industry Association (SIA) is promoting the Creating Helpful Incentives to Produce Semiconductors (CHIPS) for America Act, introduced in Congress in June 2020. An SIA press release describes the bill as "bipartisan legislation that would invest tens of billions of dollars in semiconductor manufacturing incentives and research initiatives over the next 5-10 years to strengthen and sustain American leadership in chip technology, which is essential to our country's economy and national security."

On June 8, 2021, the Senate approved \$52 billion for the CHIPS for America Act, dedicated to supporting the U.S. semiconductor industry over the next decade. This paper highlights a curious paradox: Most of the SIA corporate members now lobbying for the CHIPS for America Act have squandered past support that the U.S. semiconductor industry has received from the U.S.

\footnotetext{
${ }^{*}$ William Lazonick, UMass professor of economics emeritus, is president of the Academic-Industry Research Network, an Open Societies Foundations Fellow, and a Canadian Institute for Advanced Research Fellow. Matt Hopkins is a senior research fellow at the Academic-Industry Research Network and a PhD candidate at SOAS University of London. Research for this article has been funded by the Institute for New Economic Thinking. We thank Thomas Ferguson, Ken Jacobson, and Öner Tulum for comments.
} 
government for decades by using their corporate cash to do buybacks to boost their own companies' stock prices. Among the SIA corporate signatories of a letter to President Biden in February 2021, the five largest stock repurchasers-Intel, IBM, Qualcomm, Texas Instruments, and Broadcom - did a combined \$249 billion in buybacks over the decade 2011-2020, equal to 71 percent of their profits and almost five times the subsidies over the next decade for which the SIA is lobbying. In addition, among the members of the Semiconductors in America Coalition (SIAC), formed specifically in May 2021 to lobby Congress for the passage of the CHIPS for America Act, are Apple, Microsoft, Cisco, and Google. These firms spent a combined \$633 billion on buybacks during 2011-2020. That is about 12 times the government subsidies provided under the CHIPS for America Act to support semiconductor fabrication in the United States in the upcoming decade.

If the Congress wants to achieve the legislation's stated purpose of promoting major new investments in semiconductors, it needs to deal with this paradox. It could, for example, require

the SIA and SIAC to extract pledges from its member corporations that they will cease doing stock buybacks as open-market repurchases over the next ten years. Such regulation could be a first step in rescinding Securities and Exchange Commission Rule 10b-18, which has since 1982 been a major cause of extreme income inequality and loss of global industrial competitiveness in the United States.

\section{https://doi.org/10.36687/inetwp165}

JEL codes: D01, D21, D25, D40, G22, G28, G35, G38, L21, L52, L63

Key words: Semiconductor fabrication, nanometer technology, global competition, CHIPS for America Act, Semiconductor Industry Association, Semiconductors in America Coalition, stock buybacks, Intel, TSMC, Samsung Electronics, IBM, GlobalFoundries, Apple, semiconductor fabrication equipment, Huawei. 


\section{The CHIPS for America Act}

On February 11, 2021, the Semiconductor Industry Association (SIA), representing 26 U.S.based corporations as charter members, ${ }^{1}$ sent a letter to President Joe Biden, asking him "to include in your recovery and infrastructure plan substantial funding for incentives for semiconductor manufacturing, in the form of grants and/or tax credits, and for basic and applied semiconductor research." The SIA claimed that the decline of the U.S. share of global semiconductor manufacturing capacity from 37 percent in 1990 to 12 percent in 2020 "is largely because the governments of our global competitors offer significant incentives and subsidies to attract new semiconductor manufacturing facilities, while the U.S. does not."2

The legislation that the SIA was promoting to Biden is the Creating Helpful Incentives to Produce Semiconductors (CHIPS) for America Act, introduced in Congress in June 2020 as part of the FY2021 National Defense Authorization Act. It is, to quote an SIA press release, "bipartisan legislation that would invest tens of billions of dollars in semiconductor manufacturing incentives and research initiatives over the next 5-10 years to strengthen and sustain American leadership in chip technology, which is essential to our country's economy and national security."3

In September 2020, SIA published a report, Government Incentives and US Competitiveness in Semiconductors, commissioned from the Boston Consulting Group, with the warning that over the next decade "only $6 \%$ of the new global capacity in development will be located in the US. In contrast, it is projected that over the next decade China will add about $40 \%$ of the new capacity and become the largest semiconductor location in the world." that a $\$ 50$ billion [government] incentive program would enable the construction of 19 advanced fabs in the US over the next ten years, doubling the number expected if no action is taken and increasing the capacity located in the US by $57 \%$." 5

On June 8, 2021, the Senate approved \$52 billion for the CHIPS for America Act, dedicated to supporting the U.S. semiconductor industry over the next decade. ${ }^{6}$ But this request for major new public funds is paradoxical, almost self-defeating from a public interest standpoint. As we document in this Working Paper, most of the SIA corporate members now lobbying for the CHIPS for America Act have squandered the support that the U.S. semiconductor industry has received from the U.S. government for decades by using their corporate cash to do buybacks for the purpose of boosting their own companies' stock prices.

1 Semiconductor Industry Association, "SIA members: Working together to advance the U.S, semiconductor industry," SIA website, accessed September 11, 2021.

2 SIA Board of Directors, Letter to the Honorable Joe Biden, President of the United States, $\underline{\text { Semiconductor }}$ Industry Association, February 11, 2021.

3 Semiconductor Industry Association, "CHIPS for America would strengthen U.S. semiconductor manufacturing innovation," Semiconductor Industry Association press release, June 10, 2020.

4 Antonio Varas, Raj Varadarajan, Jimmy Goodrich, and Falan Yinug, Government Incentives and US Competitiveness in Semiconductors, Boston Consulting Group and Semiconductor Industry Association, September 2020.

5 Ibid., p. 2.

6 Will Knight, "The US needs to get back in the business of making chips," Wired, July 14, 2021. 
The historical record sharply contradicts the SIA's claim in the letter to President Biden that the U.S. government has not helped to fund the U.S. semiconductor industry. Where electronics is concerned, the United States has had the most powerful developmental state in history, ${ }^{7}$ and U.S. government funding, including procurement, has been integral to the microelectronics revolution and U.S. global leadership of it. ${ }^{8}$ As an important example, between 1987 and 1992, the U.S. government provided $\$ 500$ million in matching funds to Sematech, a nonprofit consortium of 14 semiconductor firms for the purpose of supporting the competitiveness of U.S. semiconductor equipment producers. ${ }^{9}$ In 2001, the U.S. government launched the National Nanotechnology Initiative (which aggregates funding from as many as 20 federal agencies), with budgets totaling $\$ 12.1$ billion for 2001-2010 and \$16.9 billion for 2011-2020, with proposed 2021 spending of $\$ 1.7$ billion. $^{10}$

The blame for U.S. loss of global semiconductor fabrication leadership rests heavily with financialized U.S. companies, ${ }^{11}$ including most of the 20 corporations whose senior executives, as SIA directors, signed the letter to President Biden. From among these 20 companies, Table 1 displays distributions to shareholders in the form of dividends and buybacks as well as investment in productive capabilities in the form of plant \& equipment and research \& development expenditures by the five largest repurchasers for the decade 2011-2020. These five companies, which accounted for over 87 percent of the $\$ 287$ billion in buybacks executed by the 19 publicly listed signatory companies over the decade, ${ }^{12}$ did almost five times the spending on buybacks during those ten years as the $\$ 52$ billion that the Senate has approved to provide

7 Matt Hopkins and William Lazonick, "Who Invests in the High-Tech Knowledge Base?" Institute for New Economic Thinking Working Group on the Political Economy of Distribution Working Paper No. 6, September 2014 (revised December 2014), in which, besides extensive empirical documentation, there is a discussion of the concept of the "developmental state" as applied to the United States,

8 John E. Tilton, International Diffusion of Technology: The Case of Semiconductors, Brookings Institution, 1971; National Research Council, Funding a Revolution: Government Support for the Computing Industry, National Academies Press, 1999; Janet Abbate, Inventing the Internet, MIT Press, 1999; National Research Council, Securing the Future: Regional and National Programs to Support the Semiconductor Industry, National Academies Press, 2003; Stuart Leslie, "The Biggest 'Angel' of Them All: The Military and the Making of Silicon Valley," in Martin Kenney, ed., Understanding Silicon Valley: The Anatomy of an Entrepreneurial Region, Stanford University Press, 2000: 48-67; Michaela D. Platzer and John F. Sargent Jr., "U.S Semiconductor Manufacturing: Industry Trends, Global Competition, Federal Policy," Congressional Research Service, R44544, June 27, 2016.

9 Douglas A. Irwin and Peter J. Klenow, "Sematech: Purpose and Performance," Proceedings of the National Academy of Sciences of the United States of America, 93, 29, 1996: 12739-12742; Larry D. Browning and Judy C. Shetler, Sematech: Saving the U.S. Semiconductor Industry, Texas A\&M University Press, 2000; Robert D. Hof, "Lessons from Sematech," MIT Technology Review, July 25, 2011; Richard Van Atta and Marko M. G. Slusarczuk, "The Tunnel at the End of the Light: The Future of the U.S. Semiconductor Industry," Issues in Science and Technology, Spring 2012: 53-60. The 14 original members of Sematech were Advanced Micro Devices, Compaq Computer, Conexant, Harris Semiconductor, Hewlett-Packard, IBM, Intel, LSI Logic, Lucent Technologies, Micron Technology, Motorola, NCR Microelectronics, National Semiconductor, Rockwell International, and Texas Instruments. See National Research Council, Securing the Future, p. 98.

${ }^{10}$ These data are on the website of the U.S. National Nanotechnology Initiative.

${ }^{11}$ For the key case of Intel, see William Lazonick and Matt Hopkins, "How Intel Financialized and Lost Leadership in Semiconductor Fabrication,” Institute for New Economic Thinking, July 7, 2021.

${ }^{12}$ Stock buybacks done, 2011-2020, by the other 14 companies whose executives signed the letter to President Biden were (in billions) Nvidia $\$ 5.3$, Western Digital $\$ 4.5$, Marvell Technology $\$ 4.2$, Xilinx $\$ 4.2$ billion, Micron Technology \$3.9, Skyworks Solutions \$3.7, Qorvo \$3.5, Maxim Integrated Products \$3.1, Analog Devices \$2.6, ON Semiconductor $\$ 1.2$, Cree $\$ 0.9$, Silicon Laboratories $\$ 0.5$, Lattice Semiconductor $\$ 0.1$, and AMD $\$ 0.0$. 
subsidies to the U.S. semiconductor industry for ten years going forward under the CHIPS for America Act.

The main purpose of these hundreds of billions of dollars in buybacks has been to give boosts to the stock prices of the repurchasing companies. ${ }^{13}$ As a result of buybacks, a company's stock price increases a) if, as is typically the case, stock traders bid up the price when a company announces a repurchase program giving the CEO and CFO the authority (but not the obligation) to do a certain value of open-market repurchases (say, $\$ 10$ billion) over a certain time period (say, three years); b) when, at the direction of the CFO, the actual execution of buybacks by the company's broker on any particular day or series of days increases the market demand for the company's shares; and c) if, with the release of the company's quarterly financial report, the increase in the company's earnings per share (EPS) because of the reduction in shares outstanding prompts stock traders to bid up the price of the company's stock even more.

Table 1. Distributions to shareholders and investments in productive capabilities, 2011-2020, by the five largest repurchasers among members of the Semiconductor Industry Association

\begin{tabular}{|c|c|c|c|c|c|c|}
\hline & Intel & IBM & Qualcomm & $\begin{array}{c}\text { Texas } \\
\text { Instruments }\end{array}$ & Broadcom & $\begin{array}{l}\text { Total, five } \\
\text { companies }\end{array}$ \\
\hline REV, \$b & 614 & 875 & 221 & 138 & 117 & 1,964 \\
\hline $\mathrm{NI}, \$ \mathrm{~b}$ & 140 & 116 & 43 & 35 & 21 & 355 \\
\hline \multicolumn{7}{|l|}{ Distributions } \\
\hline $\mathrm{DV}, \$ \mathrm{~b}$ & 49 & 48 & 26 & 18 & 16 & 158 \\
\hline$B B, \$ b$ & 80 & 73 & 54 & 28 & 13 & 247 \\
\hline $\mathrm{DV}+\mathrm{BB}, \$ \mathrm{~b}$ & 128 & 121 & 80 & 46 & 29 & 404 \\
\hline DV/NI\% & 35 & 42 & 60 & 51 & 77 & 44 \\
\hline $\mathrm{BB} / \mathrm{NI} \%$ & 57 & 63 & 124 & 78 & 61 & 70 \\
\hline$(\mathrm{DV}+\mathrm{BB}) / \mathrm{NI} \%$ & 92 & 105 & 184 & 129 & 139 & 114 \\
\hline \multicolumn{7}{|l|}{ Investments } \\
\hline$R \& D, \$ b$ & 119 & 58 & 50 & 15 & 23 & 284 \\
\hline$P \& E, \$ b$ & 117 & 34 & 9 & 7 & 5 & 176 \\
\hline$R \& D+P \& E, \$ b$ & 236 & 92 & 60 & 22 & 28 & 460 \\
\hline R\&D/REV\% & 19 & 7 & 23 & 11 & 19 & 14 \\
\hline P\&E/REV\% & 19 & 4 & 4 & 5 & 4 & 9 \\
\hline (R\&D+P\&E)/REV\% & 38 & 11 & 27 & 16 & 24 & 22 \\
\hline
\end{tabular}

Note: $\mathrm{REV}=$ revenues, $\mathrm{NI}=$ net income $\mathrm{DV}=$ cash dividends, $\mathrm{BB}=$ stock buybacks, $\mathrm{R} \& \mathrm{D}=$ research and development expenditures, $\mathrm{P} \& \mathrm{E}=$ plant and equipment expenditures. It is conventional, and correct, business practice to use percentages of net income as the comparative metric for distributions to shareholders and percentages of revenues as the comparative metric for investments in the firm's productive capabilities.

${ }^{13}$ William Lazonick, "Profits Without Prosperity: Stock Buybacks Manipulate the Market and Leave Most Americans Worse Off," Harvard Business Review, September 2014: 46-55; William Lazonick, "Stock Buybacks: From Retain and Reinvest to Downsize-and-Distribute," Brookings Institution, April 17, 2015; William Lazonick, Mustafa Erdem Sakinç and Matt Hopkins "Why Stock Buybacks are Dangerous for the Economy," $\underline{\text { Harvard }}$ Business Review, January 7, 2020. 
Under the U.S. Securities and Exchange Commission's Rule 10b-18, adopted in November 1982, which grants a company a safe harbor against stock-price manipulation charges in doing massive buybacks as open-market repurchases, ${ }^{14}$ the company does not reveal, even after the fact, the precise days on which buybacks are done. Yet the company's senior executives are obviously in possession of this information, while professional stock traders can detect when the company's broker is executing large-scale buybacks. ${ }^{15}$

The prime beneficiaries of this stock-price manipulation have been the same corporate executives, who, as "value-extracting insiders," decide how much to spend on buybacks and when to do them. ${ }^{16}$ Also reaping the gains from buybacks have been professional stock traders at Wall Street banks and hedge funds who, as "value-extracting outsiders," are in the business of timing the buying and selling of corporate shares on the stock markets. ${ }^{17}$ Among the hedge-fund managers are certain shareholder activists who purchase a small fraction of a company's shares on the stock market and then, to encourage the insiders to do buybacks, line up the proxy votes of asset managers, who function as "value-extracting enablers." 18

Instead of spending cash on buybacks, the semiconductor companies listed in Table 1 and other interested corporations to which we refer in this article could have easily funded the investments in U.S. semiconductor fabrication that they now want U.S. taxpayers to support. The remainder of this article details the facts that the public and Congress should consider as they consider whether and how to use public money to help business actors who have been and, in most cases, remain well positioned to invest in U.S. semiconductor capabilities but have chosen instead to pursue self-interested financial gain.

\section{Intel's financialized business model}

\footnotetext{
${ }^{14}$ Lazonick, "Stock Buybacks"; Lenore Palladino, "The \$1 Trillion Question: New Approaches to Regulating Stock Buybacks," Yale Journal of Regulation, 36, 2018: 89-105; Ken Jacobson and William Lazonick, "License to Loot: Opposing Views of Capital Formation and the Adoption of SEC Rule 10b-18," The Academic-Industry Research Network, forthcoming.

${ }^{15}$ See, for example, John Ramsay, Investors Exchange LLC, Letter to Brent J. Fields, Securities Exchange Commission, March 27, 2018, in which the author of the letter states: "As the global head of trading at a large asset manager put it: "When it comes to handling the corporate buyback, what's painfully obvious to us is that the corporate buyback is probably the most gameable order in the marketplace. If you pursue liquidity in a corporate buyback algorithm, other participants can easily sense how the algorithm is going to react and try to trade in front of it.' We are in full agreement with this statement."

${ }^{16}$ William Lazonick, "The Value-Extracting CEO: How Executive Stock-Based Pay Undermines Investment in Productive Capabilities," Structural Change and Economic Dynamics, 48, 2019: 53-68.

17 William Lazonick and Jang-Sup Shin, Predatory Value Extraction: How the Looting of the Business Corporation Became the US Norm and How Sustainable Prosperity Can Be Restored, Oxford University Press, January 2020, chs. 6 and 7.

18 Ibid., ch. 5. Jang-Sup Shin, "The Subversion of Shareholder Democracy and the Rise of Hedge-Fund Activism," Institute for New Economic Thinking Working Paper No. 77, July 2018.
} 
Intel leads the global semiconductor industry in total revenues. But, as an integrated device manufacturer (IDM), Intel produces almost all its central processors (CPUs) at 14nm, ${ }^{19}$ while, since 2018, the company's implementation of more technologically advanced $10 \mathrm{~nm}$ capacity has been stuck, with limited output. ${ }^{20}$ Meanwhile, Apple, an important Intel customer, is abandoning Intel processors for its Mac computers, turning instead to Taiwan Semiconductor Manufacturing Company (TSMC) to fabricate chips that Apple itself designs. ${ }^{21}$ As we discuss below, since 2015 TSMC has been fabricating all of Apple's smartphone chips on the most advanced technology platforms, and currently Apple commands almost all of TSMC's most advanced 5nm production capacity. Intel itself already contracts with TSMC and Taiwan's United Microelectronics Corporation (UMC) to manufacture 15-20 percent of its non-CPU chips. Moreover, later this year, TSMC will commence production of Intel's Core i3 processors for advanced laptops at $5 \mathrm{~nm} .{ }^{22}$

Even as it has fallen behind in advanced chip fabrication, Intel has remained a very profitable company, averaging $\$ 21.0$ billion in annual net income in 2018-2020, with average annual plant \& equipment (P\&E) expenditures of $\$ 15.2$ billion. In 2021, Intel expects to produce its first $7 \mathrm{~nm}$ CPU, while increasing P\&E spending to \$20 billion. As part of its IDM 2.0 strategy for manufacturing, innovation, and product leadership, announced in March by the company's new CEO, Pat Gelsinger, Intel plans to build two fabs in Arizona. ${ }^{23}$ Included in IDM 2.0 is the launch of Intel Foundry Services "with plans to become a major provider of foundry capacity in the U.S. and Europe to serve customers globally."24

Yet even if Intel should achieve $7 \mathrm{~nm}$ on a significant scale in 2021, as this decade unfolds it could fall further behind TSMC, the worldwide fabrication leader, and Samsung Electronics Corporation, which ranks second in global foundry revenues. At some point, Intel could even find itself trailing Semiconductor Manufacturing International Corporation (SMIC), the leading Chinese foundry, especially if China responds to U.S. trade restrictions by developing a semiconductor-equipment supply chain so that it is not dependent on U.S. vendors. ${ }^{25}$

19 Note that nm stands for nanometer, with lower numbers (e.g., $5 \mathrm{~nm}$ compared with $7 \mathrm{~nm}$ ) indicating more advanced technology related to power, thermal, speed, and miniaturization characteristics of the chips that can be produced. See, e.g., Diwas Poudel, "What is nm in processor?: $5 \mathrm{~nm}, 7 \mathrm{~nm}, 10 \mathrm{~nm}$, and 24nm in processor size," Ourtechroom, August 28, 2021.

20 A. Souppouris, “A strong Intel is what the tech industry needs right now," Engadget, March 24, 2021. On Intel's problems with implementing advanced nanometer platforms, see, e.g., Renee Johnson, "Intel outlines its struggles with 10-nm chip production," The Tech Report, April 30, 2018; Anton Shilov, "Intel's 10nm node: Past, present, and future," EETimes, June 15, 2020; Anton Shilov, "Intel's 10nm node: Past, present, and future-part 2,"

EETimes, June 17, 2020; Paul Alcorn, “Intel's 7nm is broken, company announces delay until 2022, 2023," Tom's Hardware, July 23, 2020; Yatharth Sood, "Intel's troubles in shrinking down," Medium, August 7, 2020.

21 Kif Leswing, "Apple is breaking a 15-year partnership with Intel on its Macs-here's why," $\underline{C N B C}$, November $10,2020$.

${ }^{22}$ Luke James, “Intel set to outsource select CPU production to TSMC's 5nm process," AllAboutCircuits, January $20,2021$.

23 “'Intel CEO Pat Gelsinger announces 'IDM 2.0' strategy for manufacturing, innovation and product leadership, Intel Press Release, March 23, 2021.

24 Ibid.

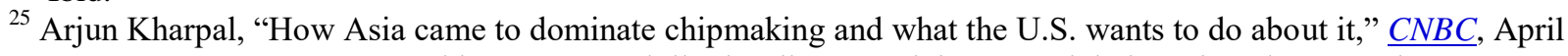
11, 2021; Rich Karlgaard, "China's trillion-dollar hurdle to crack into top global semiconductor ranks," Forbes, September 10, 2021. 
In our view, the main explanation for Intel's lag behind TSMC as well as Samsung in advanced semiconductor manufacturing derives from its focus on doing stock buybacks to support its stock price. ${ }^{26}$ In the years 2011-2015, Intel was in the running, along with TSMC and Samsung, to be the fabricator of the iPhone, iPad, and iPod chips that Apple designed. While Intel spent $\$ 50$ billion on P\&E and $\$ 53$ billion on R\&D over those five years, it also lavished shareholders with $\$ 35$ billion in stock buybacks and $\$ 22$ billion in cash dividends, which together absorbed 100 percent of Intel's net income (see Table 2).

From 2016 through 2020, Intel spent $\$ 67$ billion on P\&E and $\$ 66$ billion on R\&D, but also distributed almost $\$ 27$ billion as dividends and another $\$ 45$ billion as buybacks. Intel's ample dividends have provided an income yield to shareholders for, as the name says, holding Intel shares. In contrast, the funds spent on buybacks have rewarded sharesellers, including senior Intel executives with their stock-based pay, for executing well-timed sales of their Intel shares to realize gains from buyback-manipulated stock prices.

Table 2. Intel: stock buybacks, cash dividends, plant and equipment expenditures, and research and development expenditures, with ratios to net income and revenues, 1991-2020

\begin{tabular}{|c|c|c|c|c|c|c|c|c|c|c|c|}
\hline & $\begin{array}{l}\text { REV } \\
\$ b\end{array}$ & $\begin{array}{l}\text { NI } \\
\text { \$b }\end{array}$ & $\begin{array}{l}\text { BB } \\
\$ b\end{array}$ & $\begin{array}{l}\text { DV } \\
\$ b\end{array}$ & $\begin{array}{c}\text { P\&E, } \\
\$ b\end{array}$ & $\begin{array}{c}R \& D \\
\$ b\end{array}$ & $\begin{array}{l}\text { BB/ } \\
\text { NI\% }\end{array}$ & $\begin{array}{l}\text { DV/ } \\
\text { NI\% }\end{array}$ & $\begin{array}{c}(\mathrm{BB}+\mathrm{DV}) / \\
\mathrm{NI} \%\end{array}$ & $\begin{array}{l}\text { P\&E/ } \\
\text { REV\% }\end{array}$ & $\begin{array}{l}\text { R\&D/ } \\
\text { REV\% }\end{array}$ \\
\hline 1991-1995 & 47 & 10 & 2 & 0 & 10 & 5 & 21 & 3 & 24 & 21 & 10 \\
\hline 1996-2000 & 135 & 36 & 20 & 1 & 21 & 14 & 56 & 4 & 60 & 16 & 11 \\
\hline 2001-2005 & 156 & 26 & 30 & 5 & 25 & 22 & 115 & 17 & 133 & 16 & 14 \\
\hline 2006-2010 & 190 & 33 & 17 & 15 & 26 & 30 & 51 & 44 & 95 & 14 & 16 \\
\hline 2011-2015 & 271 & 57 & 35 & 22 & 50 & 53 & 61 & 39 & 100 & 18 & 19 \\
\hline 2016-2020 & 343 & 83 & 45 & 27 & 67 & 66 & 54 & 32 & 86 & 20 & 19 \\
\hline
\end{tabular}

Note: $\mathrm{REV}=$ revenues, $\mathrm{NI}=$ net income $\mathrm{DV}=$ cash dividends, $\mathrm{BB}=$ stock buybacks, $\mathrm{R} \& \mathrm{D}=$ research and development expenditures, $\mathrm{P} \& \mathrm{E}=$ plant and equipment expenditures.

Source: Intel 10-K filings.

As Table 3 shows, Intel's distributions to shareholders have been far greater than those made by either Samsung Electronics or TSMC. The purpose of Samsung Electronic's stock buybacks in 2002-2007 and 2014-2018, in contrast to those of Intel, was to augment the voting power of the founding Lee family, thereby consolidating their strategic control over resource allocation against the threat of corporate raiders. ${ }^{27}$ It is clear from Samsung's remarkable history that the Lee family has used its strategic control to allocate profits to investments in world-class productive capabilities. So too at TSMC under the leadership of its founder and long-time chairman and CEO Morris Chang. At 50 percent of net income over the past decade, TSMC's dividend payout ratio was 2.8 times that of Samsung Electronics and 1.4 times that of Intel. But the remaining 50 percent of profits were available for investment in the company. The sole purpose of TSMC's stock repurchases between 2003 and 2008 was to buy out the ownership

\footnotetext{
${ }^{26}$ The following paragraphs on Intel draw upon Lazonick and Hopkins, "How Intel Financialized."

${ }^{27}$ Samsung Electronics, Form 20-F filings; Jonathan Cheng and Min-Jeong Lee, "Samsung to buy back \$2 billion worth of shares," Wall Street Journal, November 26, 2014.
} 
stake of Philips, the Netherlands-based electronics giant that in 1987 had partnered with the Taiwanese government in founding TSMC. ${ }^{28}$

Innovation requires financial commitment to sustain technological transformation and market access until the generation of a higher-quality, lower-cost product can result in financial returns. $^{29}$ The foundation of financial commitment is retained earnings. In the case of Intel, as shown in Table 1 above, in recent years the company has made substantial allocations to P\&E and $R \& D$, even as it has distributed almost all its profits to shareholders. ${ }^{30}$ In making productive investments, however, Intel has been able to tap other cash flows, including, over 2011-2020, depreciation charges of $\$ 87$ billion, long-term debt issues of $\$ 45$ billion, stock sales (mainly to employees as stock-based compensation plans) of $\$ 12$ billion, and divestitures of $\$ 5$ billion.

Given the availability of these sources of funds, the vast sums that Intel has wasted on buybacks have not thus far imposed a cash constraint on its investments in semiconductor fabrication. Rather, it has been a deficiency in organizational learning - the essence of the innovation process - that has hampered Intel's implementation of process technology. The generation of high levels of productivity from $\mathrm{P} \& \mathrm{E}$ and $\mathrm{R} \& \mathrm{D}$ expenditures requires organizational integration, in addition to financial commitment. Organizational integration mobilizes the skills and efforts of large numbers of people in a hierarchical and functional division of labor into the collective and cumulative learning processes required to transform technologies to generate a higherquality product and access markets to attain economies of scale.

Table 3. Stock buybacks and cash dividends as percentages of net income at Intel, Samsung Electronics, and TSMC, 2001-2020

\footnotetext{
${ }^{28}$ TSMC, Form 20-F filings; "Philips to sell its 16.2\% stake in Taiwan's TSMC," New York Times, March 9, 2007.

${ }^{29}$ William Lazonick, "The Theory of Innovative Enterprise: Foundations of Economic Analysis," in Thomas Clarke, Justin O'Brien, and Charles R. T. O'Kelley, eds., The Oxford Handbook of the Corporation, Oxford University Press, 2019: 490-514.

${ }^{30}$ Note that R\&D is accounted for as a current expense, so only year-to-year increments to R\&D spending must be financed out of profits or other sources of funds such as depreciation, debt, or equity issues.
} 


\begin{tabular}{|c|c|c|c|c|c|c|c|c|c|c|c|c|}
\hline & \multicolumn{4}{|c|}{ Intel } & \multicolumn{4}{|c|}{ Samsung Electronics } & \multicolumn{4}{|c|}{ TSMC } \\
\hline & $\mathbf{N I}, \$ \mathbf{b}$ & DV/NI\% & BB/NI\% & $\begin{array}{c}(\mathrm{DV}+\mathrm{BB}) / \\
\mathrm{N} / \%\end{array}$ & $\mathbf{N I}, \$ \mathbf{b}$ & DV/NI\% & BB/NI\% & $\begin{array}{c}(\mathrm{DV}+\mathrm{BB}) / \\
\mathrm{NI} \%\end{array}$ & $\mathbf{N I}, \mathbf{\$ b}$ & DV/NI\% & BB/NI\% & $\begin{array}{c}(\mathrm{DV}+\mathrm{BB}) / \\
\mathrm{NI} \%\end{array}$ \\
\hline 2001 & 1.3 & 42 & 310 & 352 & 2.2 & 17 & 0 & 17 & 0.4 & 0 & 0 & 0 \\
\hline 2002 & 3.1 & 17 & 129 & 146 & 5.9 & 5 & 21 & 26 & 0.6 & 0 & 0 & 0 \\
\hline 2003 & 5.6 & 9 & 71 & 80 & 5.0 & 15 & 33 & 48 & 1.4 & 1 & 28 & 28 \\
\hline 2004 & 7.5 & 14 & 100 & 114 & 10.3 & 15 & 36 & 50 & 2.9 & 13 & 8 & 21 \\
\hline 2005 & 8.7 & 23 & 123 & 145 & 7.5 & 11 & 28 & 39 & 2.9 & 50 & 0 & 50 \\
\hline 2006 & 5.0 & 46 & 91 & 137 & 8.5 & 10 & 23 & 33 & 3.9 & 49 & 0 & 49 \\
\hline 2007 & 7.0 & 38 & 28 & 66 & 8.4 & 10 & 23 & 33 & 3.4 & 71 & 42 & 112 \\
\hline 2008 & 5.3 & 59 & 134 & 193 & 4.7 & 22 & 0 & 22 & 3.1 & 77 & 34 & 110 \\
\hline 2009 & 4.4 & 71 & 38 & 109 & 8.8 & 9 & 0 & 9 & 2.8 & 86 & 0 & 86 \\
\hline 2010 & 11.5 & 31 & 13 & 44 & 14.2 & 12 & 0 & 12 & 5.5 & 48 & 0 & 48 \\
\hline 2011 & 12.9 & 32 & 109 & 141 & 11.9 & 6 & 0 & 6 & 4.4 & 58 & 0 & 58 \\
\hline 2012 & 11.0 & 40 & 43 & 83 & 22.3 & 5 & 0 & 5 & 5.7 & 47 & 0 & 47 \\
\hline 2013 & 9.6 & 47 & 22 & 69 & 28.9 & 4 & 0 & 4 & 6.2 & 42 & 0 & 42 \\
\hline 2014 & 11.7 & 38 & 92 & 130 & 20.3 & 10 & 5 & 16 & 8.4 & 29 & 0 & 29 \\
\hline 2015 & 11.4 & 40 & 26 & 66 & 16.9 & 16 & 26 & 43 & 9.3 & 38 & 0 & 38 \\
\hline 2016 & 10.3 & 48 & 25 & 73 & 21.3 & 13 & 31 & 44 & 10.2 & 47 & 0 & 47 \\
\hline 2017 & 9.6 & 53 & 38 & 90 & 37.3 & 16 & 20 & 36 & 11.6 & 53 & 0 & 53 \\
\hline 2018 & 21.1 & 26 & 51 & 77 & 40.3 & 23 & 2 & 25 & 11.9 & 57 & 0 & 57 \\
\hline 2019 & 21.0 & 26 & 65 & 91 & 18.7 & 44 & 0 & 44 & 11.8 & 73 & 0 & 73 \\
\hline 2020 & 20.9 & 27 & 68 & 95 & 22.4 & 37 & 0 & 37 & 18.1 & 50 & 0 & 50 \\
\hline 2001-2020 & 199.0 & 34 & 64 & 98 & 315.8 & 16 & 10 & 27 & 124.6 & 50 & 2 & 53 \\
\hline 2001-2010 & 59.4 & 32 & 79 & 112 & 75.6 & 12 & 17 & 29 & 26.8 & 50 & 11 & 62 \\
\hline 2011-2020 & 139.6 & 35 & 57 & 92 & 240.2 & 18 & 8 & 26 & 97.7 & 50 & 0 & 50 \\
\hline
\end{tabular}

Note: $\mathrm{NI}=$ net income $\mathrm{DV}=$ cash dividends, $\mathrm{BB}=$ stock buybacks.

Sources: Intel 10-K filings; TSMC and Samsung Electronics 20-F filings.

The root of Intel's failure in organizational integration lies in the financialized character of strategic control within the company. Accepting stock yield as the measure of enterprise performance, in recent years Intel's senior executives who exercise strategic control have lacked the incentive and, in some cases, the ability, to implement innovative investment strategies through organizational integration. From May 2005 to February 2021, the forte of two of Intel's three CEOs-Paul Otellini (2005-2013) and Robert Swan (2018-2021)—was financial engineering rather than technological engineering.

As indicated in Table 2 above, Intel was already engaged in significant stock buybacks under CEOs Andrew Grove (1987-1998) and Craig Barrett (1998-2005), both of whom had deep technological expertise. Since the 1980s, executive stock-based pay, in the form of stock options and stock awards, has created incentives for Intel's CEOs to do large-scale buybacks to boost the company's stock price. Table 4 documents the total compensation, including realized gains from stock options and stock awards, of Intel's CEOs over the past three decades. Of the total compensation that Grove took home from 1992 through 1997, 90 percent was realized gains from stock-based pay, with 89 percent of the \$170 million flowing into his bank account in 1996 and 1997 as the Internet stock-market boom took off. ${ }^{31}$ Aided by the boom and a doubling of

\footnotetext{
${ }^{31}$ On the correct measure of executive pay in terms of realized gains from stock-based pay, see Matt Hopkins and William Lazonick, “The Mismeasure of Mammon: Uses and Abuses of Executive Pay Data,” Institute for New Economic Thinking Working Paper No. 49, August 29, 2016; William Lazonick and Matt Hopkins, "If the SEC measured CEO pay packages properly, they would look even more outrageous," Harvard Business Review, December 22, 2016,
} 
Intel's buybacks to $\$ 6.8$ billion in 1998, Barrett's total compensation in his first year as CEO was $\$ 117$ million, with 98 percent of it realized gains from exercising stock options.

Table 4. Total and stock-based remuneration of Intel CEOs, 1992-2020

\begin{tabular}{|c|l|c|c|c|c|c|c|c|}
\hline $\begin{array}{c}\text { Years for } \\
\text { which CEO } \\
\text { pay is } \\
\text { available }\end{array}$ & Intel CEO & $\begin{array}{c}\text { Total pay, } \\
\mathbf{\$ m}\end{array}$ & $\begin{array}{c}\text { Annual } \\
\text { average pay, } \\
\mathbf{\$ m}\end{array}$ & $\begin{array}{c}\text { \% of total } \\
\text { from stock } \\
\text { options }\end{array}$ & $\begin{array}{c}\text { \% of total } \\
\text { from stock } \\
\text { awards }\end{array}$ & $\begin{array}{c}\text { \% of total } \\
\text { from stock- } \\
\text { based pay }\end{array}$ & $\begin{array}{c}\text { Average } \\
\text { annual } \\
\text { dividends, } \\
\mathbf{\$ m}\end{array}$ & $\begin{array}{c}\text { Average } \\
\text { annual } \\
\text { buybacks, } \\
\mathbf{\$ m}\end{array}$ \\
\hline $\mathbf{1 9 9 2 - 1 9 9 7}$ & Andrew S. Grove & 170 & $\mathbf{2 8}$ & 90 & 0 & 90 & 107 & 1,126 \\
\hline $\mathbf{1 9 9 8 - 2 0 0 4}$ & Craig R. Barrett & $\mathbf{2 1 3}$ & $\mathbf{3 0}$ & 91 & 0 & 91 & 524 & 4,993 \\
\hline $\mathbf{2 0 0 5 - 2 0 1 2}$ & Paul S. Otellini & 96 & $\mathbf{1 2}$ & 30 & 21 & 51 & 3,136 & 6,020 \\
\hline $\mathbf{2 0 1 3 - 2 0 1 7}$ & Brian M. Krzanich & 99 & $\mathbf{2 0}$ & 24 & 48 & 72 & 4,688 & 4,487 \\
\hline $\mathbf{2 0 1 8 - 2 0 2 0}$ & Robert H. Swan & $\mathbf{3 8}$ & $\mathbf{1 3}$ & 0 & 57 & 57 & 5,562 & 12,845 \\
\hline
\end{tabular}

Note: Stock-based pay is measured as the actual realized gains from the exercise of stock options and vesting of stock awards.

This table provides publicly available data on CEO pay at Intel. Unavailable are comparable data for Grove prior to 1992 and for certain portions of years in which CEO transitions occurred.

Source: Intel DEF 14A proxy filings.

Intel's buybacks reached $\$ 10.6$ billion in 2005, the year in which Otellini, Intel's first nonengineer CEO, took over. Buybacks declined to an average of $\$ 1.7$ billion in 2008 and 2009 in reaction to the financial crisis but then were jacked up to as high as $\$ 14.3$ billion in 2011. The following year, buybacks were $\$ 5.1$ billion, as Otellini banked $\$ 40$ million in total compensation, of which 82 percent was stock-based.

With Krzanich as CEO, buybacks peaked at $\$ 10.8$ billion in 2014 . He raked in $\$ 40$ million in total pay (79 percent stock-based) in 2017 but was ousted in mid-2018 for having a "consensual relationship" with an Intel employee. ${ }^{32}$ In early 2018, news outlets alleged that Krzanich engaged in insider trading, based on non-public information of security flaws in Intel's CPUs, as he sold all his Intel shares except for the minimum 250,000 he was required by contract to hold. ${ }^{33}$

With Krzanich's exit, the new CEO was Robert Swan, an MBA who had spent his career in finance at a number of companies, including GE, TRW, Northrup Grumman, eBay, and General Atlantic, before joining Intel as CFO in 2016. From 2018 through 2020, Swan averaged just under $\$ 13$ million in total remuneration, of which 57 percent was stock-based. In the Swan years, annual dividends were 19 percent higher and annual buybacks 186 percent higher than in the Krzanich years.

\section{Intel's corporate collaborators in the clamor for government subsidies}

The second largest stock repurchaser among the SIA-member signatories of the letter to Biden was IBM (see Table 1). This once-iconic U.S. corporation, which dates back to 1913, entered the

\footnotetext{
${ }^{32}$ Sara Salinas, "Intel's Brian Krzanich is forced out as CEO after 'consensual relationship' with employee,” $\underline{C N B C}$, June 21, 2018.

${ }^{33}$ Jeremy C. Owens, "Intel CEO sold millions of stock after company was informed of vulnerability, before disclosure," MarketWatch, January 4, 2018.
} 
1990s as the world's leading computer company, designing and producing chips for its mainframe computers and outsourcing the microprocessor for the IBM PC to Intel. Throughout the 1980s, IBM continued to tout its "career-with-one-company" business model, with a policy of no involuntary layoffs. All that changed in the first half of the 1990s, however, as IBM reduced its employment from 373,816 at the end of 1990 to 219,839 four years later, definitively and deliberately putting an end to its "lifelong employment" practices. ${ }^{34}$

The company now preferred younger, less expensive workers with the latest "open system" computer skills related to its PC business rather than older, more expensive career employees with IBM-specific system-integration capabilities related to its mainframe business. This strategic reorientation entailed a two-decades long shift of IBM out of hardware to focus on software and services. IBM also became focused on "maximizing shareholder value." 35 After the drastic downsizing of its labor force in the first half of the 1990s, IBM began distributions to shareholders in the form of massive buybacks, even as, without fail from 1996 through 2020, the company increased its annual dividend payouts. IBM did \$51.4 billion in buybacks (79 percent of net income) in 1995-2004 and \$119.7 billion (93 percent) in 2005-2014.

IBM could have invested the funds spent on buybacks in state-of-the-art fabs, but, as part of its abandonment of hardware, in 2015 the company sold its semiconductor facilities to GlobalFoundries (GF), whose CEO was also among the signatories of the February 2021 letter to Biden. With its corporate headquarters in New York State, GF does not do open-market repurchases because it is privately held by Mubadala, an Abu Dhabi sovereign wealth fund. GF was launched in 2009 with fabs that had belonged to U.S.-based Advanced Micro Devices (AMD), which has subsequently been fabless. GF is second worldwide only to TSMC in pureplay foundry revenues. In 2018, however, GF decided to cease investing in $10 \mathrm{~nm}$ and $7 \mathrm{~nm}$ fabrication technologies, contributing to U.S. loss of competitiveness in the segment.

Indeed, IBM is currently suing GF for "fraud and intentional breaches of contract" for its failure to make these investments in advanced technology since it relies on GF for the fabrication of its chips. ${ }^{36}$ As IBM has put it in its lawsuit: "IBM would not agree, and did not agree, to form such a technology alliance until GlobalFoundries gave its representation and assurance that it had made a long-term strategic and financial commitment to the development of High Performance chips." IBM is quite clear about why it thinks GF has failed to invest in advanced technologies: "GlobalFoundries had no explanation for deliberately backtracking on its representations and breaching the parties' agreements — other than its own arrogance and greed."

Yet with its $\$ 120$ billion in buybacks in the decade before it sold its fabs to GF, IBM's senior executives were no strangers to arrogance and greed. ${ }^{37}$ In May 2010, IBM CEO Sam Palmisano

\footnotetext{
${ }^{34}$ William Lazonick, Sustainable Prosperity in the New Economy? Business Organization and High-Tech Employment in the United States, W. E. Upjohn Institute for Employment Research, 2009, chs. 3-4.

35 Ibid.

36 Timothy Prickett Morgan, "Why is IBM suing GlobalFoundries over chip roadmap failures," Thenextplatform, June 10, 2021.

37 See Harvard Business Review, "Managing Investors (interview with IBM CEO Sam Palmisano)," Harvard Business Review, June 2014: Hopkins and Lazonick, "Who Invests in the High-Tech Knowledge Base," pp. 6167.
} 
announced the company's earnings per share (EPS) "road map," the objective of which was to reach at least \$20 EPS by the end of $2015 .^{38}$ That would double IBM's EPS of \$10.01 in 2009, which was up from $\$ 3.76$ six years earlier. ${ }^{39}$ Along with revenue growth and operating leverage, IBM cited stock repurchases as a driver in achieving its EPS objective. ${ }^{40}$ One way in which IBM sought to increase "operating leverage," and hence jack up EPS, was through layoffs. ${ }^{41}$ At the end of 2011, IBM's headcount was 433,362; at the end of 2015, 377,757.

From 2010 through 2014, IBM did $\$ 70$ billion in buybacks (92 percent of net income) which followed $\$ 50$ billion in buybacks in 2005-2009 (93 percent of net income). But with revenues and profits in sharp decline in 2014, the reduction of shares outstanding through buybacks was not enough to keep IBM's EPS on track for the \$20 2015 target, and in October 2014, IBM CEO Virginia Rometty, who had succeeded Palmisano on January 1, 2012, revealed that IBM was abandoning its EPS road map. ${ }^{42}$ At the exact same time, IBM announced the sale of its fabs to GF for $\$ 1.5$ billion. $^{43}$

At the end of 2020, IBM employed 345,900 people. With its net income in 2020-2021 at less than one-third its level in 2012-2013, the company did only \$302 million in buybacks in 2020 and has done none thus far in 2021. But its dividend is almost 50 percent higher in 2020-2021 than in 2012-2013, now absorbing 115 percent of net income compared with 24 percent when IBM was hellbent on achieving its EPS road map and was shedding employees and, by 2015, its fabs. Now IBM, along with GF and Intel, want U.S. taxpayers to fork over $\$ 52$ billion in incentives and subsidies to rebuild U.S. capabilities in semiconductor fabrication.

The hypocrisy of Intel, IBM, and GF in requesting government support applies to the other four SIA members whose buyback activity is displayed in Table 1. Texas Instruments (TI) was once a world leader in semiconductor-manufacturing innovation; Jack Kilby invented the integrated circuit at TI in $1958 .^{44}$ Like Intel, TI is an IDM that, to manufacture the chips that it designs, has ten wafer fabs worldwide, of which six are located in the United States. ${ }^{45}$ The company is an important supplier of semiconductors to a variety of industries, including automotive.

But TI has not been investing in cutting-edge fab technology. As shown in Table 1, at five percent, TI's investment in P\&E as a proportion of revenues is in line with those of IBM, Qualcomm, and Broadcom, all of which are fabless (and, hence, are inherently less P\&E-

${ }^{38}$ Ritsuko Ando, “IBM aims to double profit by 2015," Reuters, May 12, 2010.

39 IBM, Annual Report 2009, p. 12.

${ }^{40}$ IBM, Annual Report 2011, p. 11.

${ }^{41}$ Heidi Moore, "IBM fires small-town workers work for Wall Street numbers," The Guardian, March 2, 2014; Nick Summers, "The trouble with IBM," Bloomberg, May 22, 2014; Steve Denning, "Why IBM is in decline," Forbes, May 30, 2014.

42 Jessica Menton, "IBM abandons roadmap 2015," International Business Times, October 20, 2014.

${ }^{43}$ Ibid.; Joel Hruska, "IBM sells chip business to GlobalFoundries for $\$ 1.5$ billion (updated)," Extremetech, October 20, 2014.

${ }^{44}$ T. R. Reid, The Chip: How Two Americans Invented the Microchip and Launched a Revolution, Simon \& Schuster. The other American referenced in the book's title was Robert Noyce, who was working at Fairchild Semiconductor when he invented another version of the integrated circuit in 1959 and went on to co-found Intel with Gordon Moore in 1968.

${ }^{45}$ Texas Instruments, “TI at a Glance,” Texas Instruments press release, accessed September 14, 2021. 
intensive), while, at 11 percent, TI's R\&D spending as a proportion of revenues is far lower than all of the companies in Table 1 except IBM. In 2011-2020, at $\$ 28$ billion, TI's spending on buybacks was four times its P\&E spending. Why would Congress want to use taxpayer dollars to incentivize and subsidize TI to undertake investments in fab capacity that it could have easily made itself?

As for Qualcomm and Broadcom, they are innovative chip-design companies that, in the fabless segment of the semiconductor industry, ranked \#1, and \#2 respectively in global revenues in $2020 .{ }^{46}$ Over the past decade, these two companies spent a combined $\$ 69.6$ billion on buybacks. If access to more and better semiconductor manufacturing capacity in the United States had been important to these companies, they could have used the huge sums dissipated on buybacks to invest in one or more of the U.S-based fabs which they now profess to need so badly.

Investments in U.S.-based fab capacity could have also been made by many other highly profitable companies with a direct interest in semiconductors, some of which are members of the Semiconductors in America Coalition (SIAC), a trade organization formed in May 2021 specifically to lobby Congress for the passage of the CHIPS for America Act. SIAC describes itself as a "cross-sector alliance of companies that make and use semiconductors, [with a] mission...to help bolster America's economy, critical infrastructure, and national security by advancing semiconductor manufacturing and research in the U.S." ${ }^{47}$ In July, SIAC sent a letter to the majority and minority leaders of the House and Senate "to urge Congress to support funding for incentives for semiconductor manufacturing and increased semiconductor research," including the $\$ 52$ billion in the CHIPS Act. ${ }^{48}$

Among the members of SIAC are Apple, Microsoft, Cisco Systems, and Google (whose parent corporation is Alphabet), which, for the decade 2011-2020, ranked \#1, \#3, \#6, and \#9, respectively, among all U.S. industrial companies in buyback activity, with \$378 billion, \$110 billion, $\$ 76$ billion, and $\$ 69$ billion. $^{49}$ That is $\$ 633$ billion spent on buybacks over the past decade by these four companies, which have lent their corporate weight to industry's demand for $\$ 52$ billion to support the U.S. semiconductor industry over the next decade. For 2011-2020, these four tech companies plus the five SIA members in Table 1 raked in a total of $\$ 1.3$ trillion in net income, of which 66 percent went to buybacks and another 30 percent to dividends. So why do these companies and many others that have participated in the SIA and SIAC lobbying efforts need $\$ 52$ billion from the federal government to save the U.S. semiconductor fabrication industry?

\section{Why hasn't Apple invested in fabs?}

\footnotetext{
${ }^{46}$ Peter Clarke, "Qualcomm overtakes Broadcom in top ten fabless company list," eeNews, December $23,2020$.

47 SIAC, "Semiconductor industry and downstream sector leaders form collation to secure federal investments in domestic chip manufacturing and research," Semiconductors in America Coalition press release, May 11, 2021.

${ }^{48}$ SIAC, Letter to Speaker Pelosi, Leader Schumer, Leader McConnell, and Leader McCarthy, Semiconductors in America Coalition, July 28, 2021.

49 Data analysis by the Academic-Industry Research Network, using the S\&P Compustat database and company 10K filings. Ranked \#2 among U.S. industrial companies in buyback activity with \$133 billion for 2011-2020 was Oracle, which, however, is not a member of SIAC. Intel and IBM, which are members of SIAC as well as SIA, ranked \#5 with $\$ 80$ billion and \#8 with $\$ 73$ billion, respectively.
} 
Among these nine companies, for the decade 2011-2020 Apple alone accounted for 34 percent of the profits, 43 percent of the buybacks, and 25 percent of the dividends. From October 2012 through June 2021, Apple did \$444 billion in buybacks, equal to 87 percent of the company's net income, with another 22 percent of net income devoted to dividends. In October 2014, as Apple was being pressured by hedge-fund activist Carl Icahn to do a \$150-billion buyback, ${ }^{50}$ Lazonick published on the website of Harvard Business Review an open letter to Apple CEO Tim Cook, in which he suggested a number of ways in which Apple could invest in innovative capabilities rather than do buybacks. ${ }^{51}$ At that time, Apple had done $\$ 68$ billion in buybacks in two years, with twice as much in FY2014 compared with FY2013, as the company had already responded to the predations of Icahn, who had purchased less than one percent of Apple's outstanding shares toward the end of FY2013. ${ }^{52}$

Now, seven years later, with Apple having done $\$ 444$ billion in buybacks over the past nine years, a specific question that Cook should answer is why the company that he leads has not used some of those funds to invest in one or more state-of-the-art semiconductor fabs. Indeed, this question was posed to Apple before it went on its buyback binge. In 2010, when Steve Jobs was still the company's CEO, a prominent electronics-industry journalist, Mark LaPedus, published a column entitled "Apple should build a fab." 53

At the time Apple was reliant for chip fabrication on its emerging smartphone competitor, Samsung Electronics. Moreover, LaPedus thought that Jobs' management style would favor investing in a fab. As the journalist put it:

I believe Jobs wants more control of the supply (and perhaps manufacturing) chain to buffer his company from the chip industry's boom and bust cycles. In boom times, for example, foundries struggle to keep up with demand, and OEM customers are at a disadvantage - a position from which strong egos don't like to negotiate.

On the competitive advantages and financial feasibility of Apple building its own fab, LaPedus continued:

I could see Apple building a traditional, smaller-scale logic fab to gain more control over the A4 [processors] and its follow-ons. Logic fabs can cost $\$ 4$ billion to maybe $\$ 10$ billion to build out, depending on the tool sets, but Apple could swing the funding. I am sure Texas would pick up some of the tab for a new fab on its soil. The same goes for New York. In an age when real men go fabless, I concede it's an unconventional idea.

\footnotetext{
${ }^{50}$ William Lazonick, "Numbers Show Apple Shareholders Have Already Gotten Plenty," Harvard Business Review, October 16, 2014.

${ }^{51}$ William Lazonick, "What Apple Should Do with Its Massive Piles of Money," Harvard Business Review, October 20, 2014. See also William Lazonick, Mariana Mazzucato and Öner Tulum "Apple's Changing Business Model: What Should the World's Richest Company Do With All Those Profits?" Accounting Forum, 37, 4, 2013: 249267.

52 Lazonick, "Numbers Show Apple Shareholders Have Already Gotten Plenty"; William Lazonick, Matt Hopkins, and Ken Jacobson "What We Learn About Inequality from Carl Icahn's \$2 Billion Apple 'No Brainer'," Institute for New Economic Thinking Perspectives, June 6, 2016.

${ }^{53}$ Mark LaPedus, “Apple should build a fab,” $\underline{E D N}$, August 26, 2010.
} 
You might think it's absurd. But an Apple A4 fab today could keep the iProduct franchise in hay — and Samsung at bay.

Jobs passed away in October 2011. Would he have seen the wisdom in LaPedus' suggestion as the demand for iPhones continued to escalate? In August 2011, Jobs had handed over the CEO position to Cook, the Apple executive who had added value to the company by outsourcing manufacturing of devices to Hon Hai, enabling the Taiwanese company's Foxconn subsidiary in China to emerge as the world's leading electronics manufacturing services provider. ${ }^{54}$

Jobs knew that when he had been absent from Apple between 1985 and 1997 the company had almost gone bankrupt after doing large-scale distributions to shareholders in the form of both dividends and buybacks. ${ }^{55}$ Whether he would have acceded to Apple's buybacks is another question that cannot be answered. But we do know that under CEO Cook, Apple started doing enormous repurchases in fiscal 2013 and, as the numbers show, the company has been on a world record-breaking buyback binge ever since.

As for the fabrication of its iPhone processors, between 2011 and 2015 Apple shifted its contract from Samsung Electronics, which had emerged as its top competitor in the smartphone market, to TSMC, which from 1987 had pioneered the "pure play" foundry model. Apple is now T-MC's largest customer, accounting for about 25 percent of its total revenues. ${ }^{56}$ TSMC and Samsung Electronics are now the world's leading chip manufacturers, with U.S.-based Intel having fallen significantly behind in the implementation of advanced nanometer technology. ${ }^{57}$

This past April, TSMC announced plans to spend $\$ 100$ billion in total on P\&E and R\&D over the next three years. Included in TSMC's investment plan is a \$12-billion 5nm facility in Arizona to fabricate Apple's M-series processors. ${ }^{58}$ By June 2021, TSMC had begun construction of the new Arizona fab, with the first chips scheduled for delivery in $2024 .{ }^{59}$ That TSMC is investing billions of dollars in advanced chip fabrication in the United States may seem fine and good, until one reflects on the fact that, as a nation, the United States now lags in a critical industry in which it was once the world leader, while Taiwan, which the United States does not even formally recognize as an independent nation, has significant political leverage as a result of TSMC's investments in semiconductor innovation.

In potentially providing $\$ 52$ billion of taxpayers' money to support the U.S. semiconductor industry under the CHIPS for America Act, federal lawmakers should also consider that TSMC's

\footnotetext{
54 “Foxconn rides partnership with Apple to take 50 percent of EMS market in 2011," July 27, iSuppli, 2010; Tripp Mickle and Yoko Kubota, "Tim Cook and Apple bet everything on China. Then coronavirus hit." Wall Street Journal, March 3, 2020.

55 Lazonick et al, "Apple's Changing Business Model."

56 Lazonick and Hopkins, "How Intel Financialized."

57 Ibid.

58 Anton Shilov, "TSMC plans to spend $\$ 100 \mathrm{~B}$ on fabs and R\&D over the next three years: $2 \mathrm{~nm}$, Arizona fab \& more," AnandTech, April 2, 2021.

59 Cheng Ting-Fang and Lauly Li, "TSMC starts construction of \$12bn Arizona chip plant," Nikkei Weekly, June 2, 2021.
} 
multiyear investment of $\$ 12$ billion in a state-of the-art fab in Arizona pales in comparison to the vast sums that Apple has been routinely spending on buybacks: $\$ 73$ billion in 2018, $\$ 69$ billion in 2019, $\$ 72$ billion in 2020, and $\$ 66$ billion in the first nine months of 2021. A country, never mind one enormously rich company, could have built a lot of state-of-the-art fabs with all that cash.

\section{Weaponizing U.S. semiconductor equipment companies in the trade war with China}

Instead of investing in innovation, in the past year Apple has actually benefited immensely from TSMC's dominance of advanced chip fabrication by ridding itself of a formidable smartphone competitor, China's Huawei Technologies. In May 2020, as a key part of the Trump administration's trade war with China, the U.S. government began to coerce TSMC to cease selling chips to Huawei. ${ }^{60}$

Coming into the fourth quarter of 2020, TSMC's second-largest customer, after Apple, was HiSilicon, the Chinese chip-design company, wholly owned by Huawei. In 2019, Apple had accounted for 24 percent of TSMC's revenues and Hi-Silicon 15 percent, and in the third quarter of 2020 TSMC began shipping smartphone chips to the Chinese company produced on the fabricator's 5nm technology. ${ }^{61}$ In May 2019, Huawei had surpassed Apple to become the world's second-largest smartphone producer ${ }^{62}$ and in April 2020 had also overtaken Samsung to become the world leader. ${ }^{63}$ In the third quarter of 2020, 59 percent of TSMC's revenues came from North America, followed by 22 percent from China. ${ }^{64}$ In the fourth quarter of 2020 , revenues from North America soared to 73 percent of TSMC's total, while those from China plummeted to six percent, ${ }^{65}$ as TSMC complied with U.S. government directives to cut off Huawei's chip supply completely.

The result of this U.S. trade policy, which has been maintained by the Biden administration, has been a dramatic decline in Huawei's smartphone sales. By the second quarter of 2021, Huawei was not even among the top five smartphones sold in China, although its Honor brand, which Huawei had spun off as an independent company to avoid U.S. sanctions, held fifth place. ${ }^{66}$ With no chips going to Huawei from the fourth quarter of 2020, TSMC abruptly lost its second largest customer. Yet from 3Q20 to 4Q20 TSMC's smartphone revenues increased from 46 percent to 51 percent of total sales and its profits rose by 4.0 percent. At the same time, $5 \mathrm{~nm}$ wafer revenue, predominantly from the fabrication of the most advanced smartphone processors, which had been zero percent of TSMC's total in 2Q20 and eight percent in 3Q20, jumped to 20 percent in 4Q20. In supporting TSMC's revenues and profits by increasing its purchase of $5 \mathrm{~nm}$ chips,

${ }^{60}$ David Shepardson, Karen Freifeld, and Alexandra Alper, "U.S. moves to cut Huawei off from global chip suppliers as China eyes retaliation," Reuters, May 15, 2020.

${ }^{61}$ Alan Friedman, "U.S, export rule change puts TSMC and Huawei in a bind over shipment of cutting-edge $5 \mathrm{~nm}$ silicon," phoneArena, September 20, 2020.

${ }^{62}$ Lisa Eadicicco, "Huawei, the Chinese tech giant embroiled in controversy, just overtook Apple to become the second-largest smartphone maker," Business Insider, May 3, 2019.

${ }^{63}$ Zak Doffman, "Apple and Samsung beaten by Huawei in huge new smartphone surprise," Forbes, June 15, 2020.

${ }^{64}$ TSMC, “3Q20 Quarterly Management Report," TSMC, October 15, 2020, p.2.

${ }^{65}$ TSMC, “4Q20 Quarterly Management Report," TSMC, January 14, 2020, p.2.

${ }^{66}$ Yordan, "IDC: Huawei is no longer a Top 5 smartphone company in China," GSMArena, July 27, 2021; Bloomberg News, "Huawei posts sharpest drop in quarterly sales since U.S. ban," Bloomberg, August 6, 2021. 
Apple in effect partnered with the U.S. government to demolish the smartphone business of Huawei, its prime global competitor.

TSMC and the government of Taiwan, which is a founding shareholder in the company, have taken an enormous geopolitical risk in implementing U.S. trade sanctions against Huawei, China's most successful technology company. The main weapon that the U.S. government used to enforce TSMC's compliance with its ban on supplying chips to Huawei was the threat that it would cut off the sale to the Taiwanese chipmaker of semiconductor equipment by U.S.-based companies, and in particular Applied Materials, Lam Research, and KLA, which in 2020 ranked $\# 1$, \#3, and \#5, respectively, among the world's semiconductor-equipment suppliers. ${ }^{67}$

The positions of Applied Materials, Lam Research, and KLA as global leaders in the equipment segment owe a great deal to U.S. government policy in the late 1980s and 1990s. All three companies emerged from Silicon Valley between 1967 and 1980 as that industrial district became central to the microelectronics revolution. By the mid-1980s, however, as Japanese companies captured global memory-chip fabrication from U.S.-based companies such as Intel, Motorola, National Semiconductor, and Texas Instruments, the threat arose that Japanese firms would dominate the semiconductor-equipment segment as well. In response, 14 U.S. companies received U.S. government antitrust dispensation to collaborate in founding the non-profit research consortium Sematech, which received $\$ 500$ million in federal government funding between 1989 and 1996. ${ }^{68}$ When Sematech launched its operations in Austin, Texas, in 1989, an article in the local newspaper noted that "Silicon Valley companies, including Applied Materials Inc., Lam Research Inc. and KLA Instruments Inc., say they are coming here to be closer to opportunities at Sematech—and to be closer to their competitors." 69

Back then, Applied Materials, Lam Research, and KLA retained their profits and reinvested in innovative capabilities, propelling their growth. Applied Materials, which expanded from 2,651 employees in 1989 to 19,220 in 2000, did its first large-scale buybacks in 2004 and paid its first dividends in 2005. Lam Research, which increased its employment from 731 in 1989 to 3,708 in 2000, did its first large-scale buybacks in 2007 and paid its first dividends in 2015. KLA (called KLA-Tencor from 1997 to 2019), with 991 employees in 1989 and 5,800 in 2000, began paying dividends in 2005 and did its first large-scale buybacks in 2007. Since then, as shown in Table 5, having caught the "American disease," all three companies have become addicted to buybacks.

Yet it was the investments in innovative capabilities that these three companies made over several decades that enabled the U.S. government to weaponize them in its war on Huawei. And the data in Table 5 indicate that the profits that these companies are now making by selling equipment around the world will be used to prop up their stock prices. History suggests that if these companies remain focused on the destructive goal of "maximizing shareholder value,"

\footnotetext{
${ }^{67}$ The Chip Insider, "2020 top semiconductor equipment suppliers,” VLSIResearch, March 11, 2021. Netherlandsbased ASML was \#2 and Japan-based Tokyo Electron was \#4.

${ }^{68}$ Browning and Shetler, Sematech: Saving the U.S. Semiconductor Industry; Hof, "Lessons from Sematech," The 14 founding companies were Advanced Micro Devices, Digital Equipment, Harris Semiconductor, Hewlett-Packard, IBM, Intel, LSI Logic, Micron Technology, Motorola, NCR, National Semiconductor, Rockwell International, and Texas Instruments. See Irwin and Klenow, "Sematech: Purpose and Performance."

${ }^{69}$ Kyle Pope, "Consortium starts to lure other firms," Austin American-Statesman, April 3, 1989.
} 
innovative equipment suppliers, most likely based outside the United States, will take over the segment's top spots in the next decade or two. ${ }^{70}$

${ }^{70}$ See, for example, William Lazonick, "The Financialization of the U.S. Corporation: What Has Been Lost, and How It Can Be Regained," Seattle University Law Review, 36, 2, 2013: 857-909; Marie Carpenter and William Lazonick, "Innovation, Competition, and Financialization in the Communications Technology Industry," ISIGrowth Working Paper 08/2017, May, 2017; Öner Tulum and William Lazonick, "Financialized Corporations in a National Innovation System: The US Pharmaceutical Industry," International Journal of Political Economy, 47, 3-4, 2018: 281-316; William Lazonick and Matt Hopkins, "How 'Maximizing Shareholder Value' Minimized the Strategic National Stockpile," Institute for New Economic Thinking Working Paper No. 127, July 2020. 
Table 5. Buybacks and dividends as percentages of net income, three leading U.S.-based semiconductor equipment companies, 19912020

\begin{tabular}{|c|c|c|c|c|c|c|c|}
\hline $\begin{array}{l}\text { APPLIED } \\
\text { MATERIALS }\end{array}$ & $\mathrm{NI}, \$ \mathrm{~m}$ & $\mathrm{DV}, \$ \mathrm{~m}$ & $\mathrm{BB}, \$ \mathrm{~m}$ & DV/NI\% & $\mathrm{BB} / \mathrm{NI} \%$ & $\begin{array}{c}(\mathrm{DV}+\mathrm{BB}) / \\
\mathrm{NI} \%\end{array}$ & $\begin{array}{l}\text { Employment, } \\
\text { end of period }\end{array}$ \\
\hline 1991-1995 & 840 & 0 & 0 & 0 & 0 & 0 & 10,537 \\
\hline 1996-2000 & 4,139 & 0 & 488 & 0 & 12 & 12 & 19,220 \\
\hline 2001-2005 & 3,189 & 98 & 3,074 & 3 & 96 & 99 & 12,924 \\
\hline $2006-2010$ & 4,820 & 1,550 & 7,363 & 32 & 153 & 185 & 13,045 \\
\hline 2011-2015 & 4,740 & 2,259 & 3,454 & 48 & 73 & 121 & 15,500 \\
\hline $2016-2020$ & 14,793 & 3,037 & 11,399 & 21 & 77 & 98 & 24,000 \\
\hline $\begin{array}{l}\text { LAM } \\
\text { RESEARCH }\end{array}$ & $\mathrm{NI}, \$ \mathrm{~m}$ & $\mathrm{DV}, \$ \mathrm{~m}$ & $\mathrm{BB}, \$ \mathrm{~m}$ & DV/NI\% & $\mathrm{BB} / \mathrm{NI} \%$ & $\begin{array}{c}(\mathrm{DV}+\mathrm{BB}) / \\
\mathrm{NI} \%\end{array}$ & $\begin{array}{l}\text { Employment, } \\
\text { end of period }\end{array}$ \\
\hline 1991-1995 & 162 & 0 & 0 & 0 & 0 & 0 & 3,600 \\
\hline $1996-2000$ & 55 & 0 & 50 & 0 & 92 & 92 & 3,708 \\
\hline 2001-2005 & 337 & 0 & 262 & 0 & 78 & 78 & 2,200 \\
\hline 2006-2010 & 1,505 & 0 & 1,445 & 0 & 96 & 96 & 3,232 \\
\hline 2011-2015 & 2,294 & 116 & 2,605 & 5 & 114 & 119 & 7,300 \\
\hline $2016-2020$ & 9,436 & 2,077 & 8,317 & 22 & 88 & 110 & 11,300 \\
\hline KLA & $\mathrm{NI}, \$ \mathrm{~m}$ & $\mathrm{DV}, \$ \mathrm{~m}$ & $\mathrm{BB}, \$ \mathrm{~m}$ & DV/NI\% & $\mathrm{BB} / \mathrm{NI} \%$ & $\begin{array}{c}(\mathrm{DV}+\mathrm{BB}) / \\
\mathrm{NI} \%\end{array}$ & $\begin{array}{l}\text { Employment, } \\
\text { end of period }\end{array}$ \\
\hline 1991-1995 & 71 & 0 & 1 & 0 & 1 & 1 & 1,654 \\
\hline 1996-2000 & 653 & 0 & 98 & 0 & 15 & 15 & 5,800 \\
\hline 2001-2005 & 1,130 & 24 & 602 & 2 & 53 & 55 & 5,500 \\
\hline 2006-2010 & 957 & 503 & 2,504 & 53 & 262 & 314 & 5,000 \\
\hline 2011-2015 & 3,043 & 4,007 & 1,616 & 132 & 53 & 185 & 5,880 \\
\hline 2016-2020 & 4,825 & 2,087 & 2,334 & 43 & 48 & 92 & 10,600 \\
\hline
\end{tabular}

Source: S\&P Compustat database and company 10-K filings.

\section{Does America want a CHIPS for Buybacks Act?}

Historically, the U.S. government played a central role in investing in physical infrastructure and human capabilities that enabled the United States to be a global leader in advanced technology. ${ }^{71}$ As we suffer immensely from climate change and the SARS-CoV-2 pandemic, that role for the government in the allocation of the economy's resources is now more important than ever. But, as in the past, these government investments will only succeed in their missions if major business corporations collaborate in investing in innovation. ${ }^{72}$

Government-business technology collaborations have the best chance of success when the relevant companies are engaged in a "retain-and-reinvest" mode of corporate resource allocation: The companies retain corporate profits and reinvest in their productive capabilities, first and foremost those of their employees. The tech companies on which we have focused in the paper are now, with one exception, in what we call a "dominate-and-distribute" mode of resource

\footnotetext{
${ }^{71}$ Hopkins and Lazonick, "Who Invests in the High-Tech Knowledge Base."

72 Ibid.: Lazonick and Hopkins, "How 'Maximizing Shareholder Value' Minimized the Strategic National Stockpile"; William Lazonick, "Investing in Innovation: A Policy Framework for Attaining Sustainable Prosperity in the United States," Institute for New Economic Thinking Working Paper, October 2021 (forthcoming).
} 
allocation: Based on the innovative capabilities that they have previously developed, they dominate their industries but prioritize shareholders in the allocation of corporate resources through distributions of dividends and buybacks. The one exception is IBM, which about a decade ago transitioned from dominate-and-distribute to "downsize-and-distribute," as it slashed its global labor force from 434,246 at the end of 2012 to 345,900 at the end of 2020, while it devoted 50 percent its profits to dividends and 56 percent to buybacks over these eight years.

As an obvious immediate remedy, in passing the CHIPS for America Act, Congress could exact a pledge from the Semiconductor Industry Association and the Semiconductors in America Coalition that its member corporations will refrain from doing stock buybacks as open-market repurchases for the next ten years. ${ }^{73}$ Intel CEO Pat Gelsinger provided an opening for such a pledge when he said in an interview in May 2021 that a condition of his taking the top job at Intel three months earlier was the board's assurances that the company would "not be anywhere near as focused on buybacks going forward as we have in the past". ${ }^{74}$ In fact, in the second quarter of 2021, Intel did no buybacks, although it did increase its dividend. So, to keep such a pledge, Intel would have only nine and three-quarter years left to go.

Longer term, Congress could repeal SEC Rule 10b-18, which is nothing less than a legalized license to loot U.S. business corporations. ${ }^{75}$ The Reward Work Act, put forward by Senator Tammy Baldwin (D-WI) in March 2018 and reintroduced in March 2019, calls for rescinding Rule 10b-18 as well as placing directors representing employees on the boards of publicly listed companies. $^{76}$ In June 2019, Representatives Jesús García (D-IL) and Ro Khanna (D-CA) introduced the Reward Work Act in the House. ${ }^{77}$

As for President Biden, since coming to office he has been largely mum about buybacks, ${ }^{78}$ but that was not always the case. As vice president in the Obama administration, in October 2015

\footnotetext{
${ }^{73}$ In our view, the legislation recently proposed by Senators Sherrod Brown (D-OH) and Ron Wyden (D-OR) to impose a two-percent excise tax on the value of stock buybacks would only serve to legitimize a practice that could well be banned. Senator Sherrod Brown, "Brown Wyden unveil major new legislation to tax stock buybacks," Sen. Sherrod Brown press release, September 10, 2021. A substantial excise tax of say, 30 percent, would at least signal the economic toxicity of buybacks, analogous to taxes on cigarettes. While a study of the subject remains to be done, we would hypothesize that a ban on buybacks would increase government tax receipts as a result of higher wages, more stable employment, and enhanced productivity growth in a buyback-free U.S. economy. For a framework for such a study and its policy implications, see William Lazonick, "Investing in Innovation."

${ }^{74}$ Lesley Stahl, "Chip shortage highlights U.S. dependence on fragile supply chain,” 60 Minutes, May 2, 2021.

${ }^{75}$ Jacobson and Lazonick, "License to Loot."

${ }^{76}$ Senator Tammy Baldwin, "U.S. Senator Tammy Baldwin reintroduces legislation to rein in stock buybacks and give workers a voice on corporate boards," Sen. Baldwin press release, March 27, 2019.

${ }^{77}$ Representative Jesús "Chuy" García, "Representatives García, Khanna introduce legislation to boost jobs and wages," Rep. Garcia press release, June 10, 2019.

${ }^{78}$ Since he has been president, Biden's only mention of buybacks that we have been able to find occurred in a speech on prescription drug prices that he gave on August 12, 2021. Biden cited the findings from a House report that (in his words), "from 2016 to 2020, pharmaceutical companies spent $\$ 577$ billion in stock buybacks and dividends, 56 billion more than what they spent on all research and development over that same period of time." Pres. Joe Biden, "Joe Biden drug prices speech briefing transcript," Rev, August 12, 2021. The study to which Biden refers is a Staff Report, "Drug Pricing Investigation: Industry Spending on Buybacks, Dividends, and Executive Compensation," Committee on Oversight and Reform, U.S. House of Representatives, July 2021. See Peter Sullivan, "House report: Drug companies spent more on buybacks, dividends than research," The Hill, July
} 
Biden spoke at the first (and only) White House Summit on Worker Voice about how the union movement built the middle class. He observed that in the post-World War II decades "if you contributed to the profitability of an outfit, you got to share in the benefits." But from the 1980s the share going to workers began "shrinking, for a whole lot of reasons but some of which we can control." He then pointed out that, in the decade from 2003, major companies spent 54 percent of their profits on buybacks and another 37 percent on dividends, leaving only nine percent for reinvestment in the workforce and the future of the company. Biden continued: "How did that happen?...Y You didn't use to be able to buy back your own stock like that. Along came Reagan, new appointments [to the SEC], and guess what, you could buy back all the stock you wanted.",79

In September 2016, Biden published a Wall Street Journal op-ed, "How short-termism saps the economy," with the subhead, "Paying CEOs so much in stocks puts their focus on the share price instead of building for the long run." In the text, he noted: "Ever since the Securities and Exchange Commission changed the buyback rules in 1982, there has been a proliferation in share repurchases. Today buybacks are the norm." 80 Biden concluded the article:

The federal government can help foster private enterprise by providing worker training, building world-class infrastructure, and supporting research and innovation. But government should also take a look at regulations that promote share buybacks, tax laws that discourage long-term investment and corporate reporting standards that fail to account for long-run growth. The future of the economy depends on it. ${ }^{81}$

In an interview with the Las Vegas Sun on January 11, 2020, Biden, as a candidate for the Democratic nomination for president, criticized buybacks because they undermine investment in the corporations' workforces. As a remedy, he stated that he would reinstate the pre-Reagan limits on buyback activity. ${ }^{82}$

On March 20, 2020, candidate Biden tweeted:

I am calling on every CEO in America to publicly commit now to not buying back their company's stock over the course of the next year. As workers face the physical and economic consequences of the coronavirus, our corporate leaders cannot cede responsibility for their employees. ${ }^{83}$

11, 2021. Biden went on to say: "Look, folks, they should be able to make a significant profit." But, with the pandemic still raging, Biden did not call upon the drug companies to refrain from doing buybacks so that they could accelerate investment in innovation.

79 "The Vice President delivers remarks at the White House Summit on Worker Voice," YouTube, October 7, 2015.

80 Joe Biden, "How short-termism saps the economy," Wall Street Journal, September 27, 2016. In this article, Biden also wrote: "According to economist William Lazonick, from 2003-12, companies on the S\&P 500 spent $37 \%$ of their earnings on dividends and a full $54 \%$ on buybacks - leaving less than $10 \%$ for reinvestment.".

${ }^{81}$ Ibid. For the ways in which the attack on Delaware-based chemical company DuPont by hedge-fund activist Nelson Peltz of Trian Partners from 2013 to 2015 may have influenced Biden's thinking on corporate financialization, see Jacob M. Schlesinger, "DuPont's up-and-down history shaped Biden's views of business," Wall Street Journal, November 23, 2020.

${ }^{82}$ Sun Staff, "Sun's 2020 sit-down with Joe Biden shines a light on how he will lead the country," Las Vegas Sun, January $31,2021$.

${ }^{83}$ Joe Biden, @ JoeBiden, March 20, 2020. 
Or as then Vice President Biden put it five years ago in the closing words of his Wall Street Journal op-ed: "The future of the economy depends on it."

\footnotetext{
${ }^{84}$ Biden, "How short-termism saps the economy."
} 


\section{References}

Abbate, Janet, Inventing the Internet, MIT Press, 1999.

Alcorn, Paul "Intel's 7nm is broken, company announces delay until 2022, 2023," Tom's Hardware, July 23, 2020.

Ando, Ritsuko, “IBM aims to double profit by 2015,” Reuters, May 12, 2010.

Baldwin, Tammy, "U.S. Senator Tammy Baldwin reintroduces legislation to rein in stock buybacks and give workers a voice on corporate boards," Sen. Baldwin press release, March 27, 2019.

Biden, Joe, "How short-termism saps the economy," Wall Street Journal, September 27, 2016.

Biden, Joe, @ JoeBiden, March 20, 2020.

Biden, Joe, "Joe Biden drug prices speech briefing transcript," Rev, August 12, 2021.

Brown, Sherrod, "Brown Wyden unveil major new legislation to tax stock buybacks," Sen. Sherrod Brown press release, September 10, 2021.

Browning, Larry D., and Judy C. Shetler, Sematech: Saving the U.S. Semiconductor Industry, Texas A\&M University Press, 2000.

Carpenter, Marie, and William Lazonick, "Innovation, Competition, and Financialization in the Communications Technology Industry," ISIGrowth Working Paper 08/2017, May, 2017.

Cheng ,Jonathan, and Min-Jeong Lee, "Samsung to buy back \$2 billion worth of shares," Wall Street Journal, November 26, 2014.

Clarke, Peter, "Qualcomm overtakes Broadcom in top ren fabless company list," eeNews, December 23, 2020.

Denning, Steve, "Why IBM is in decline," Forbes, May 30, 2014.

Doffman, Zak, “Apple and Samsung beaten by Huawei in huge new smartphone surprise," Forbes, June $15,2020$.

Eadicicco, Lisa, "Huawei, the Chinese tech giant embroiled in controversy, just overtook Apple to become the second-largest smartphone maker," Business Insider, May 3, 2019.

Friedman, Alan, "U.S, export rule change puts TSMC and Huawei in a bind over shipment of cuttingedge 5nm silicon," phoneArena, September 20, 2020.

García, Jesús "Chuy”, "Representatives García, Khanna introduce legislation to boost jobs and wages," Rep. Garcia press release, June 10, 2019.

Harvard Business Review, "Managing Investors (interview with IBM CEO Sam Palmisano)," Harvard Business Review, June 2014.

Hof, Robert D., "Lessons from Sematech, MIT Technology Review, July 25, 2011.

Hopkins, Matt, and William Lazonick, "Who Invests in the High-Tech Knowledge Base?" Institute for New Economic Thinking Working Group on the Political Economy of Distribution Working Paper No. 6, September 2014 (revised December 2014).

Hopkins, Matt, and William Lazonick, "The Mismeasure of Mammon: Uses and Abuses of Executive Pay Data,” Institute for New Economic Thinking Working Paper No. 49, August 29, 2016. 
Hruska, Joel, "IBM sells chip business to GlobalFoundries for $\$ 1.5$ billion (updated)," Extremetech, October 20, 2014.

IBM, Annual Report 2009.

IBM, Annual Report 2011.

Intel 'Intel CEO Pat Gelsinger announces 'IDM 2.0' strategy for manufacturing, innovation and product leadership, Intel Press Release, March 23, 2021.

Irwin, Douglas A., and Peter J. Klenow, "Sematech: Purpose and Performance," Proceedings of the National Academy of Sciences of the United States of America, 93, 29, 1996: 12739-12742.

iSuppli, "Foxconn rides partnership with Apple to take 50 percent of EMS market in 2011," July 27, iSuppli, 2010; Tripp Mickle and Yoko Kubota, "Tim Cook and Apple bet everything on China. Then coronavirus hit." Wall Street Journal, March 3, 2020.

Jacobson, Ken, and William Lazonick, "License to Loot: Opposing Views of Capital Formation and the Adoption of SEC Rule 10b-18," The Academic-Industry Research Network, forthcoming.

James, Luke, "Intel set to outsource select CPU production to TSMC's 5nm process," AllAboutCircuits, January 20, 2021.

Johnson, Renee, "Intel outlines its struggles with 10-nm chip production," The Tech Report, April 30, 2018.

Karlgaard, Rich, "China's trillion-dollar hurdle to crack into top global semiconductor ranks," Forbes, September 10, 2021.

Kharpal, Arjun, "How Asia came to dominate chipmaking and what the U.S. wants to do about it," $\underline{C N B C}$, April 11, 2021.

Knight, Will, "The US needs to get back in the business of making chips," Wired, July 14, 2021.

LaPedus, Mark, "Why Apple should build a fab,” EDN, August 26, 2010.

Lazonick, William, Sustainable Prosperity in the New Economy? Business Organization and High-Tech Employment in the United States, W. E. Upjohn Institute for Employment Research, 2009, chs. 3-4.

Lazonick, William, "The Financialization of the U.S. Corporation: What Has Been Lost, and How It Can Be Regained," Seattle University Law Review, 36, 2, 2013: 857-909.

Lazonick, William, "Profits Without Prosperity: Stock Buybacks Manipulate the Market and Leave Most Americans Worse Off," Harvard Business Review, September 2014: 46-55.

Lazonick, William, “Numbers Show Apple Shareholders Have Already Gotten Plenty,” Harvard Business Review, October 16, 2014.

Lazonick, William, "What Apple Should Do with Its Massive Piles of Money," Harvard Business Review, October 20, 2014.

Lazonick, William, “Stock Buybacks: From Retain and Reinvest to Downsize-and-Distribute,” Brookings Institution, April 17, 2015.

Lazonick, William, "The Theory of Innovative Enterprise: Foundations of Economic Analysis," in Thomas Clarke, Justin O’Brien, and Charles R. T. O'Kelley, eds., The Oxford Handbook of the Corporation, Oxford University Press, 2019: 490-514.

Lazonick, William, "The Value-Extracting CEO: How Executive Stock-Based Pay Undermines Investment in Productive Capabilities," Structural Change and Economic Dynamics, 48, 2019: 53-68. 
Lazonick, William, "Investing in Innovation: A Policy Framework for Attaining Sustainable Prosperity in the United States," Institute for New Economic Thinking Working Paper, October 2021 (forthcoming).

Lazonick, William, and Matt Hopkins, "If the SEC measured CEO pay packages properly, they would look even more outrageous," Harvard Business Review, December 22, 2016,

Lazonick, William, and Matt Hopkins, "How 'Maximizing Shareholder Value' Minimized the Strategic National Stockpile," Institute for New Economic Thinking Working Paper No. 127, July 2020.

Lazonick, William, and Matt Hopkins, "How Intel Financialized and Lost Leadership in Semiconductor Fabrication,” Institute for New Economic Thinking, July 7, 2021.

Lazonick, William, and Jang-Sup Shin, Predatory Value Extraction: How the Looting of the Business Corporation Became the US Norm and How Sustainable Prosperity Can Be Restored, Oxford University Press, January 2020.

Lazonick, William, Matt Hopkins, and Ken Jacobson "What We Learn About Inequality from Carl Icahn's \$2 Billion Apple 'No Brainer'," Institute for New Economic Thinking Perspectives, June 6, 2016.

Lazonick, William, Mariana Mazzucato and Öner Tulum “Apple's Changing Business Model: What Should the World's Richest Company Do With All Those Profits?" Accounting Forum, 37, 4, 2013 : 249-267.

Lazonick, William, Mustafa Erdem Sakinç and Matt Hopkins "Why Stock Buybacks are Dangerous for the Economy," Harvard Business Review, January 7, 2020.

Leslie, Stuart, "The Biggest 'Angel' of Them All: The Military and the Making of Silicon Valley," in Martin Kenney, ed., Understanding Silicon Valley: The Anatomy of an Entrepreneurial Region, Stanford University Press, 2000: 48-67.

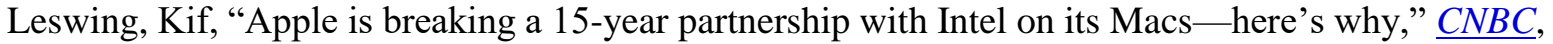
November 10, 2020.

Menton, Jessica, “IBM abandons roadmap 2015,” International Business Times, October 20, 2014.

Moore, Heidi, "IBM fires small-town workers work for Wall Street numbers," The Guardian, March 2, 2014.

Morgan, Timothy Prickett, "Why is IBM suing GlobalFoundries over chip roadmap failures," Thenextplatform, June 10, 2021.

National Research Council, Funding a Revolution: Government Support for the Computing Industry, National Academies Press, 1999.

National Research Council, Securing the Future: Regional and National Programs to Support the Semiconductor Industry, National Academies Press, 2003.

New York Times, "Philips to sell its 16.2\% stake in Taiwan's TSMC," New York Times, March 9, 2007.

Owens, Jeremy C., "Intel CEO sold millions of stock after company was informed of vulnerability, before disclosure," MarketWatch, January 4, 2018.

Palladino, Lenore, “The \$1 Trillion Question: New Approaches to Regulating Stock Buybacks," Yale Journal of Regulation, 36, 2018: 89-105.

Platzer, Michaela D., and John F. Sargent Jr., "U.S Semiconductor Manufacturing: Industry Trends, Global Competition, Federal Policy," Congressional Research Service, R44544, June 27, 2016.

Pope, Kyle, "Consortium starts to lure other firms," Austin American-Statesman, April 3, 1989. 
Poudel, Diwas, "What is $\mathrm{nm}$ in processor?: $5 \mathrm{~nm}, 7 \mathrm{~nm}, 10 \mathrm{~nm}$, and $24 \mathrm{~nm}$ in processor size," Ourtechroom, August 28, 2021.

Ramsay, John, Letter to Brent J. Fields, Securities Exchange Commission, March 27, 2018 .

Reid, T. R., The Chip: How Two Americans Invented the Microchip and Launched a Revolution, Simon $\&$ Schuster.

Salinas, Sara, “Intel's Brian Krzanich is forced out as CEO after 'consensual relationship' with employee," $\underline{C N B C}$, June 21, 2018.

Samsung Electronics, Form 20-F filings.

Schlesinger, Jacob M., "DuPont's up-and-down history shaped Biden's views of business," Wall Street Journal, November 23, 2020.

Semiconductor Industry Association, "CHIPS for America would strengthen U.S. semiconductor manufacturing innovation,” Semiconductor Industry Association press release, June 10, 2020.

Semiconductor Industry Association, "SIA members: Working together to advance the U.S, semiconductor industry," SIA website, accessed September 11, 2021.

Semiconductor Industry Association, Letter to the Honorable Joe Biden, President of the United States, Semiconductor Industry Association, February 11, 2021.

Shepardson, David, Karen Freifeld, and Alexandra Alper, "U.S. moves to cut Huawei off from global chip suppliers as China eyes retaliation," Reuters, May 15, 2020.

Shilov, Anton, “Intel's 10nm node: Past, present, and future-part 2," EETimes, June 17, 2020.

Shilov, Anton, “Intel's 10nm node: Past, present, and future,” EETimes, June 15, 2020.

Shilov, Anton, "TSMC plans to spend $\$ 100 \mathrm{~B}$ on fabs and R\&D over the next three years: $2 \mathrm{~nm}$, Arizona fab \& more," AnandTech, April 2, 2021.

Shin, Jang-Sup, "The Subversion of Shareholder Democracy and the Rise of Hedge-Fund Activism," Institute for New Economic Thinking Working Paper No. 77, July 2018.

SIAC, "Semiconductor industry and downstream sector leaders form collation to secure federal investments in domestic chip manufacturing and research," Semiconductors in America Coalition press release, May 11, 2021.

SIAC, Letter to Speaker Pelosi, Leader Schumer, Leader McConnell, and Leader McCarthy, Semiconductors in America Coalition, July 28, 2021.

Sood, Yatharth, "Intel's troubles in shrinking down," Medium, August 7, 2020.

Souppouris, A., "A strong Intel is what the tech industry needs right now," Engadget, March 24, 2021.

Staff Report, "Drug Pricing Investigation: Industry Spending on Buybacks, Dividends, and Executive Compensation," Committee on Oversight and Reform, U.S. House of Representatives, July 2021.

Stahl, Lesley, "Chip shortage highlights U.S. dependence on fragile supply chain," 60 Minutes, May 2, 2021.

Sullivan, Peter, "House report: Drug companies spent more on buybacks, dividends than research," The Hill, July 11, 2021.

Summers, Nick, "The trouble with IBM," Bloomberg, May 22, 2014.

Sun Staff, "Sun's 2020 sit-down with Joe Biden shines a light on how he will lead the country," Las Vegas Sun, January 31, 2021. 
Texas Instruments, “TI at a Glance,” Texas Instruments press release, accessed September 14, 2021.

The Chip Insider, “2020 top semiconductor equipment suppliers,” VLSIResearch, March 11, 2021.

The White House, "The Vice President delivers remarks at the White House Summit on Worker Voice," YouTube, October 7, 2015.

Tilton, John E., International Diffusion of Technology: The Case of Semiconductors, Brookings Institution, 1971.

Ting-Fang, Cheng, and Lauly Li, "TSMC starts construction of \$12bn Arizona chip plant," Nikkei

Weekly, June 2, 2021.

TSMC, “3Q20 Quarterly Management Report,” TSMC, October 15, 2020.

TSMC, “4Q20 Quarterly Management Report,” TSMC, January 14, 2020.

TSMC, Form 20-F filings.

Tulum, Öner, and William Lazonick, "Financialized Corporations in a National Innovation System: The US Pharmaceutical Industry," International Journal of Political Economy, 47, 3-4, 2018: 281-316.

Van Atta, Richard ,and Marko M. G. Slusarczuk, "The Tunnel at the End of the Light: The Future of the U.S. Semiconductor Industry," Issues in Science and Technology, Spring 2012: 53-60.

Varas, Antonio, Raj Varadarajan, Jimmy Goodrich, and Falan Yinug, Government Incentives and US Competitiveness in Semiconductors, Boston Consulting Group and Semiconductor Industry Association, September 2020.

Yordan, "IDC: Huawei is no longer a Top 5 smartphone company in China," GSMArena, July 27, 2021. Bloomberg News, "Huawei posts sharpest drop in quarterly sales since U.S. ban," Bloomberg, August 6, 2021. 